\title{
Proficient Recovery Over Records using Encryption in Cloud Computing
}

\author{
D.Vimala, K.Shanmugapriya, I. Mary Linda, C. Geetha
}

\begin{abstract}
Secure record stockpiling and recovery is one among the most blazing examination bearings in distributed computing. Notwithstanding the way that various available cryptography plans are orchestrated, few of them bolster conservative recovery over the archives that are encoded upheld their traits. Amid this paper, a positioned characteristic based cryptography topic is at first intended for a report grouping. A gathering of reports will be encoded together in the event that they share partner coordinated access structure. Contrasted and the figure content arrangement trait based cryptography $(\mathrm{CP}-\mathrm{ABE})$ plans, each the figure content cabinet reality costs of encryption/unscrambling are spared. At that point, partner record structure named trait based recovery alternatives $(A R F)$ tree is made for the report variety upheld the TF-IDF demonstrate and in this manner the archives' characteristics. The ARF tree depends on the various levelled processing encryption plot(HABE).A significance first look algorithmic program for the ARF tree is proposed to enable the chase to control that can be additional improved by parallel handling. Beside the archive accumulations, our subject will be conjointly connected to various datasets by changing the ARF tree marginally. The modification plot is called as $\mathrm{HABE}$. An extreme examination and a movement of preliminaries are executed for example the security and force of the masterminded subject.
\end{abstract}

\section{I.INTRODUCTION}

Secure record stockpiling and recovery is one among the most blazing examination bearings in distributed computing [1,2].

Revised Manuscript Received on July 22, 2019

S.Kavitha, Department of CSE, Bharath Institute of Higher Education and Research,Chennai, Tamilnadu, India.

K.ShanmugaPriya, Department of CSE, Bharath Institute of Higher Education and Research, Chennai, Tamilnadu, India.

I. Mary Linda, Department of CSE, Bharath Institute of Higher Education and Research, Chennai, Tamilnadu, India.

C. Geetha, Department of CSE, Bharath Institute of Higher

Education and Research, Chennai, Tamilnadu, India.
Notwithstanding the way that various available cryptography plans are orchestrated, few of them bolster conservative recovery over the archives that are encoded upheld their traits. Amid this paper, a positioned characteristic based cryptography topic is at first intended for a report grouping. A gathering of reports will be encoded together in the event that they share partner coordinated access structure. Contrasted and the figure content arrangement trait based cryptography $(\mathrm{CP}-$ $\mathrm{ABE}$ ) plans, each the figure contentcabinet reality costs of encryption/unscrambling are spared.

At that point, partner record structure named trait based recovery alternatives (ARF)[2] tree is made for the report variety upheld the TF-IDF demonstrate and in this manner the archives' characteristics. The ARF tree depends on the various levelled processing encryption plot(HABE).A significance first look algorithmic program for the ARF tree is proposed to enable the chase to control that can be additional improved by parallelhandling $[3,4]$. Beside the archive accumulations, our subject will be conjointly connected to various datasets by changing the ARF tree marginally. The modification plot is called as HABE. An extreme examination and a movement of preliminaries are executed for example the security and force of the masterminded subject.

\section{II.EXISTING SYSTEM}

Secure archive stockpiling and recovery is one among the most well known investigation bearings in distributed computing. Albeit a few accessible coding plans are anticipated, few of them bolster affordable recovery over the records that square measure scrambled upheld their traits. a great deal of and a ton of people and undertakings square measure spurred to source their local report the board frameworks to the cloud that might be a promising information procedure (IT) [5,6] ] to strategy the hazardous expanding of learning 


\section{Proficient Recovery Over Records using Encryption in Cloud Computing}

For verifying the information on cloud by utilizing many quality based encryption plans. An Attribute Based Encryption plot predominantly allows information get to command over information that was scrambled which can be accomplished by access approach and by attributes $[7,8]$. In this procedure is key escrow issue where single outsider specialist can unscramble the figure content which may contain touchy data. So this approach isn't satisfactory for confirming the data amassing and recuperation $[9,10]$.

Cloud figuring will gather and redesign a gigantic amount of IT assets and clearly, the cloud servers will offer progressively verify, versatile, unique, money related and altered organizations differentiated and the nearby servers. A colossal trial of re-appropriating the data to the cloud is the best way to deal with shield the protection of the informationreally however keeping up their interest limit $[11,12]$.

\section{A.Disadvantages}

Most existing plans can't bolster time productive recovery over the reports which are composed under characteristic based access control component.

Many property based encryption plans tosses key composed understanding drawback wherever single outsider specialist has the ability to revise the figure content which could contain delicate data.

Single watchword positioned seek plans and multi-catchphrase Boolean hunt plans. Nevertheless, all of these plans can't support effective, versatile and profitable report look by virtue of their direct functionalities $[13,14,15]$.

\section{III.PROPOSED SYSTEM} an equivalent

In the proposed plan, a lot of archives can share

Incorporated access tree and be encoded together as opposed to being scrambled exclusively. Along these lines, both the figure content extra room and time expenses of the encryption/unscrambling are saved. The security of the proposed arrangement is illustrated hypothetically and its adequacy is additionally assessed by reproduction.[16, 17].
To bolster precise and proficient report seek over the scrambled archives, the record structure is developed dependent on the TF-IDF display. This model executes the similitude work between the report vectors dependent on their relative likenesses in the ARF tree $[18,19]$.

A reasonable various levelled characteristic based archive variety encryption plot is anticipated amid which the records are sorted out and controlled bolstered qualities. The anticipated topic will incredibly diminish the capacity and registering loads. We tend to outline reports to vectors amid which both the watchwords and related traits are considered [20,21].

The ARF tree [22] is anticipated to mastermind the archive vectors and bolster time-effective report recovery. Moreover, a profundity first inquiry calculation is structured. An extreme re-enactment is performed to delineate the security, intensity and viability of our subject. In particular, the anticipated encryption conspire performs fine in each time and capacity power using Fig: 1 .

\section{A.Advantages}

The key age for the clients will issued by testament expert, so the crash assault isn't happens.

A profundity first look calculation for the ARF tree is intended to ensure both the hunt proficiency and exactness.

A TF/IDF demonstrate is utilized for figure similitudes among archives, this beat the time-productive recovery over the reports.

The execution of the methodology is altogether assessed by both hypothetical investigation and trials. [23, 24].

\section{IV.SYSTEM IMPLEMENTATION MODULES A.Data Owner}

Information proprietor is the duty regarding transferring the records to the cloud server and those documents are verified by key which created by the cloud specialist. Here the datasets are encoded by utilizing property based encryption calculation (ABE) [25. 26].

\section{B.Data User}

Information client is the duty regarding downloading the records from the cloud server and the downloading procedure makes by the client who gets approved from the cloud expert. Here the datasets are recovered by utilizing various levelled characteristic based encryption calculation (HABE)[27].

\section{C.Cloud Authority}

Cloud expert is the duty of key age, transmission of key to the information client and information proprietor and furthermore they give approval. Here the numerous documents are put away as ARF-tree and those are sought and recovered by utilizing profundity first pursuit calculation, HABE[28-35]. 


\section{D.Cloud Server}

Cloud server is the extra room. Here the chief is the duty regarding survey and refreshing different records in the cloud server. The individual is the obligation regarding support and the board framework for the records stockpiling [36-39].

\section{V.SYSTEM ARCHITECTURE}

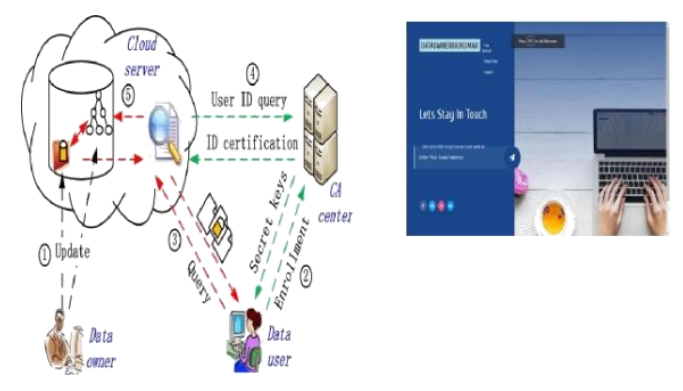

Fig:1 System Architecture

\section{VII.CONCLUSION}

This proposed framework we will in general consider a fresh out of the plastic new encoded record recovery circumstance amid which the information proprietor wants to control the reports in fine-grained level. To help this administration, we at first plan a totally extraordinaryprogressive quality based archive encryption plan to scramble an accumulation of records along that share a coordinated access structure. Further, the ARF tree[40, 41] is wanted to set up the archive vectors bolstered their likenesses. Based onCP-ABE and various levelled characteristic based encryption conspire, we extraordinarily consolidate them to help a similar record with various benefits for various clients.

\section{REFERENCES}

1. Kumarave A., RangarajanK.,Algorithm for automaton specification for exploring dynamic labyrinths,Indian Journal of Science and Technology, V-6,I-SUPPL5,PP-4554-4559,Y2013

2. P. Kavitha, S. Prabakaran "A Novel Hybrid Segmentation Method with Particle Swarm Optimization and Fuzzy CMean Based On Partitioning the Image for Detecting Lung Cancer" International Journal of Engineering and Advanced Technology (IJEAT) ISSN: 2249-8958, Volume-8 Issue-5, June 2019

3. Kumaravel A., MeeteiO.N.,An application of non-uniform cellular automata for efficient cryptography,2013 IEEE Conference on Information and Communication Technologies, ICT 2013,V-,I-,PP-1200-1205,Y-2013

4. Kumarave A., RangarajanK.,Routingalogrithm over semiregular tessellations,2013 IEEE Conference on Information and Communication Technologies, ICT 2013,V-,I-,PP-1180$1184, Y-2013$

5. P. Kavitha, S. Prabakaran "Designing a Feature Vector for Statistical Texture Analysis of Brain Tumor" International Journal of Engineering and Advanced Technology (IJEAT) ISSN: 2249-8958, Volume-8 Issue-5, June 2019

6. Dutta P., Kumaravel A.,A novel approach to trust based identification of leaders in social networks,Indian Journal of Science and Technology,V-9,I-10,PP--,Y-2016

7. Kumaravel A., DuttaP.,Application of Pca for context selection for collaborative filtering,Middle - East Journal of Scientific Research,V-20,I-1,PP-88-93,Y-2014

8. Kumaravel A., RangarajanK.,Constructing an automaton for exploring dynamic labyrinths,2012 International Conference on Radar, Communication and Computing, ICRCC 2012,V,I-,PP-161-165,Y-2012

9. P. Kavitha, S. Prabakaran "Adaptive Bilateral Filter for Multi-Resolution in Brain Tumor Recognition” International Journal of Innovative Technology and Exploring Engineering (IJITEE) ISSN: 2278-3075, Volume-8 Issue-8 June, 2019

10. KumaravelA.,Comparison of two multi-classification approaches for detecting network attacks, World Applied Sciences Journal,V-27,I-11,PP-1461-1465,Y-2013

11. Tariq J., KumaravelA.,Construction of cellular automata over hexagonal and triangular tessellations for path planning of multi-robots,2016 IEEE International Conference on Computational Intelligence and Computing Research, ICCIC 2016,V-,I-,PP--,Y-2017

12. Sudha M., KumaravelA.,Analysis and measurement of wave guides using poissonmethod,Indonesian Journal of Electrical Engineering and Computer Science,V-8,I-2,PP-546-548,Y2017

13. Ayyappan G., Nalini C., KumaravelA., Various approaches of knowledge transfer in academic social network,International Journal of Engineering and Technology,V-,I-,PP-27912794,Y-2017

14. Kaliyamurthie, K.P., Sivaraman, K., Ramesh, S. Imposing patient data privacy in wireless medical sensor networks through homomorphic cryptosystems Sciences 92. 2016, Journal of Chemical and Pharmaceutical

15. Kaliyamurthie, K.P., Balasubramanian, P.C. An approach to multi secure to historical malformed documents using integer ripple transfiguration 2016 Journal of Chemical and Pharmaceutical Sciences 92.

16. A.Sangeetha,C.Nalini,"Semantic Ranking based on keywords extractions in the web", International Journal of Engineering \& Technology, 7 (2.6) (2018) 290-292

17. S.V.GayathiriDevi,C.Nalini,N.Kumar,"An efficient software verification using multi-layered software verification tool "International Journal of Engineering \& Technology, 7(2.21)2018 454-457

18. C.Nalini,ShwtambariKharabe,"A Comparative Study On Different Techniques Used For Finger - Vein Authentication", International Journal Of Pure And Applied Mathematics, Volume 116 No. 8 2017, 327-333, Issn: 13143395

19. M.S. Vivekanandan and Dr. C. Rajabhushanam, "Enabling Privacy Protection and Content Assurance in Geo-Social Networks", International Journal of Innovative Research in Management, Engineering and Technology, Vol 3, Issue 4, pp. 49-55, April 2018.

20. Dr. C. Rajabhushanam, V. Karthik, and G. Vivek, "Elasticity in Cloud Computing", International Journal of Innovative Research in Management, Engineering and Technology, Vol 3, Issue 4, pp. 104-111, April 2018.

21. K. Rangaswamy and Dr. C. Rajabhushanamc, "CCN-Based Congestion Control Mechanism In Dynamic Networks", International Journal of Innovative Research in Management, Engineering and Technology, Vol 3, Issue 4, pp. 117-119, April 2018.

22. Kavitha, R., Nedunchelian, R., "Domain-specific Search engine optimization using healthcare ontology and a neural network backpropagation approach", 2017, Research Journal of Biotechnology, Special Issue 2:157-166

23. Kavitha, G., Kavitha, R., “An analysis to improve throughput of high-power hubs in mobile ad hoc network" , 2016, Journal of Chemical and Pharmaceutical Sciences, Vol-9, Issue-2: 361-363

24. Kavitha, G., Kavitha, R., "Dipping interference to supplement throughput in MANET" , 2016, Journal of Chemical and Pharmaceutical Sciences, Vol-9, Issue-2: $357-$ 360

25. Michael, G., Chandrasekar, A.,"Leader election based malicious detection and response system in MANET using mechanism design approach", Journal of Chemical and Pharmaceutical Sciences(JCPS) Volume 9 Issue 2, April June 2016 .

26. Michael, Chandrasekar,

G.,

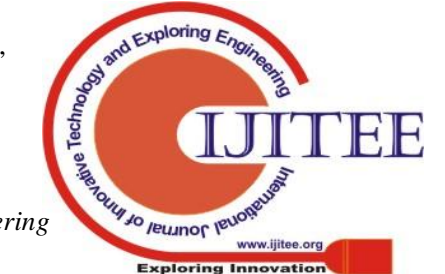




\section{Proficient Recovery Over Records using Encryption in Cloud Computing}

A.,"Modeling of detection of camouflaging worm using epidemic dynamic model and power spectral density", Journal of Chemical and Pharmaceutical Sciences(JCPS) Volume 9 Issue 2, April - June 2016

27. Pothumani, S., Sriram, M., Sridhar, J., Arul Selvan, G., Secure mobile agents communication on intranet,Journal of Chemical and Pharmaceutical Sciences, volume 9, Issue 3, Pg No S32-S35, 2016

28. Pothumani, S., Sriram, M., Sridhar, Various schemes for database encryption-a survey, Journal of Chemical and Pharmaceutical Sciences, volume 9, Issue 3, Pg NoS103S106, 2016

29. Pothumani, S., Sriram, M., Sridhar, A novel economic framework for cloud and grid computing, Journal of Chemical and Pharmaceutical Sciences, volume 9, Issue 3, Pg No S29-S31, 2016

30. Priya, N., Sridhar, J., Sriram, M. "Ecommerce Transaction Security Challenges and Prevention Methods- New Approach" 2016 ,Journal of Chemical and Pharmaceutical Sciences, JCPS Volume 9 Issue 3.page no:S66-S68

31. Priya, N.,Sridhar,J.,Sriram, M."Vehicular cloud computing security issues and solutions" Journal of Chemical and Pharmaceutical Sciences(JCPS) Volume 9 Issue 2, April June 2016 .

32. Priya, N., Sridhar, J., Sriram, M. "Mobile large data storage security in cloud computing environment-a new approach" JCPS Volume 9 Issue 2. April - June 2016

33. Anuradha.C, Khanna.V, "Improving network performance and security in WSN using decentralized hypothesis testing "Journal of Chemical and Pharmaceutical Sciences(JCPS) Volume 9 Issue 2, April - June 2016.

34. Anuradha.C, Khanna.V, "A novel gsm based control for edevices" Journal of Chemical and Pharmaceutical Sciences(JCPS) Volume 9 Issue 2, April - June 2016.

35. Anuradha.C, Khanna.V, "Secured privacy preserving sharing and data integration in mobile web environments " Journal of Chemical and Pharmaceutical Sciences(JCPS) Volume 9 Issue 2, April - June 2016.

36. Sundarraj, B., Kaliyamurthie, K.P. Social network analysis for decisive the ultimate classification from the ensemble to boost accuracy rates $2016 \quad$ International Journal of Pharmacy and Technology 8

37. Sundarraj, B., Kaliyamurthie, K.P. A content-based spam filtering approach victimisation artificial neural networks 2016 International Journal of Pharmacy and Technology $8 \quad 3$.

38. Sundarraj, B., Kaliyamurthie, K.P. Remote sensing imaging for satellite image segmentation 2016 International Journal of Pharmacy and Technology $8 \quad 3$.

39. Sivaraman, K., Senthil, M. Intuitive driver proxy control using artificial intelligence 2016 International Journal of Pharmacy and Technology $8 \quad 4$.

40. Sivaraman, K., Kaliyamurthie, K.P. Cloud computing in mobile technology 2016 Journal of Chemical and Pharmaceutical Sciences $\quad 9 \quad 2$

41. Sivaraman, K., Khanna, V. Implementation of an extension for browser to detect vulnerable elements on web pages and avoid click jacking 2016 Journal of Chemical and Pharmaceutical Sciences $\quad 9 \quad 2$.

\section{AUTHORS PROFILE}

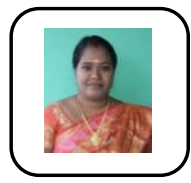

D.VimalaAssistant Professor, Department of Computer Science \& Engineering, Bharath Institute of Higher Education and Research,Chennai, India

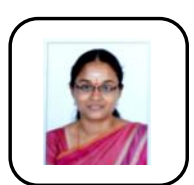

K.Shanmugha.Priya, Assistant Professor, Department of Computer Science \& Engineering, Bharath Institute of Higher Education and Research,Chennai, India

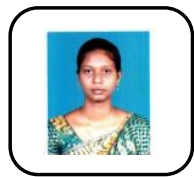

I.Mary Linda, Assistant Professor, Department of Computer Science \& Engineering, Bharath Institute of Higher Education and Research,Chennai, India

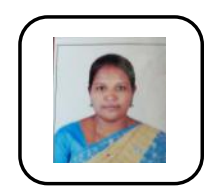

C.Geetha,Assistant Professor, Department of Computer Science \& Engineering, Bharath Institute of Higher Education and Research,Chennai, India 